\title{
Exploration of Iron Sand at The Eastern Coastal of Binangun in Cilacap Regency Using Magnetic Survey
}

\author{
Sehah*, Sukmaji Anom Raharjo and Iska Andriyanto \\ Departement of Physics, Faculty of Mathematic and Natural Science \\ University of Jenderal Soedirman \\ "Email: sehah.geophysics@gmail.com
}

\begin{abstract}
Exploration of the spread of iron sand on the eastern coastal of Binangun District in Cilacap Regency has been conducted using the magnetic surveys. The magnetic data acquisition was conducted in April 2017. The total magnetic field data obtained is processed, so that can be obtained the local magnetic anomaly data. The modeling of the local magnetic anomaly data is performed on the trajectory of $\mathrm{AB}$ that extending from the position point of $109,274698^{\circ} \mathrm{E}$ and $7.686620^{\circ} \mathrm{S}$ to $109.2296195^{\circ} \mathrm{E}$ and $7.689099^{\circ} \mathrm{S}$ so that obtained various model of the subsurface anomalous objects. Interpretation on the subsurface anomalous objects is done to estimate the types of rocks and their formations based on the magnetic susceptibility value of each object which supported by the geological information of the research area. Based on the interpretation results to be obtained two layers of subsurface rocks that can be estimated as the iron sand that coexists with silt dan clay derived from the alluvium formation. The first rock has a length of 1238.2 meters, a depth of $1.709-20.513$ meters, and a magnetic susceptibility value of $0.0183 \mathrm{cgs}$ unit. The second rock has a length of 643.055 meters, a depth of $16.524-34.188$ meters, and a magnetic susceptibility value of $0.0174 \mathrm{cgs}$ unit. The results of this research are also supported by the results of geoelectric data interpretation, where the iron sand that coexists with silt and clay is found at a depth of $9.42-19.48$ meters with a resistivity value of $52.99 \Omega \mathrm{m}$ at Geo-1 point; and a depth of $10.56-22.20$ meters with resistivity value of $49,03 \Omega \mathrm{m}$ at Geo2 point. Based on the results of of this research, the eastern coastal area of Binangun District is estimated to contain potentially iron ore and economically is a prospect for exploitation.
\end{abstract}

Keywords: Exploration, Iron Sand, Magnetic Anomaly, Eastern Coastal, Binangun District

\section{INTRODUCTION}

One of the coastal areas in Cilacap Regency estimated to contain largerly iron ore is the eastern coast of Binangun. This area is a part of the prospect area of iron ore in the coastal of Cilacap Regency, which is more than 500 hectares that spreading from Welahan Wetan Village in Binangun District to Jetis Village in Nusawungu District. The total reserves of iron ore in this area are about 744,678.85 tons, including a part of the iron ore reserves that have not yet been mined. The iron ore in this area has a magnetic degree as about $12.20 \%$ and iron content is more than $53 \%{ }^{[1]}$. Several villages in the eastern coastal of Binangun expected to have prospect for the iron sand mining, such as Sidaurip, Pagubugan Kulon, Sidayu, Pesawahan, and Widarapayung Wetan.

Iron sand is a lateritic ore with iron oxide mineral as its main content. The iron ore is obtained from iron sand, which is a sand deposit containing significant mineral iron and is generally located along the coast. Iron sand is formed due to interaction by the climate, the surface water, and the ocean waves against the origin rocks containing a iron minerals. In general, iron sand is composed of magnetite mineral $\left(\mathrm{Fe}_{3} \mathrm{O}_{4}\right)$, and small amount of silica, titanium, manganese, calcium, and vanadium. And the black iron sand on the other hand is 
generally dominated by several minerals consisting of magnetite mineral $\left(\mathrm{Fe}_{3} \mathrm{O}_{4}\right)$, hematite mineral $\left(\mathrm{Fe}_{2} \mathrm{O}_{3}\right)$, limonite mineral $\left(\mathrm{Fe}_{2} \mathrm{O}_{3} \cdot \mathrm{nH}_{2} \mathrm{O}\right)$, and siderite mineral $\left(\mathrm{FeCO}_{3}\right)^{[2]}$.

For a preliminary exploration of the iron ore distribution, general geophysical survey is carried out. One method in the geophysical survey is the magnetic method. This method is based on measurements of magnetic field variations on the earth's surface due to unequal distribution of rocks and minerals in the subsurface. The principle of this method is by utilizing the measured magnetic field variations on the earth's surface to model the subsurface anomalous objects based on their magnetic susceptibility value ${ }^{[3]}$. Therefore, this method is very suitable for exploration of the distribution of iron ore because it is easily magnetized and its magnetic susceptibility is relatively large ${ }^{[4]}$.

Basically, a magnetic object located in the subsurface of the earth, such as iron ore, can be regarded as a magnetic anomaly. Magnetic anomaly is a magnetic field derived from the distribution of magnetized subsurface minerals or rocks. According to Telford et.al (1990), a volume composed of magnetic materials can be assumed as a magnetic dipole ${ }^{[5]}$. The magnetization that occurs on the object depends on the magnitude of the magnetic induction received by the object while it is in the main magnetic field of the earth. Based on Figure 1 the magnetic potential for the whole of the magnetized object or rock volume can be formulated as:

$$
V\left(\vec{r}_{O}\right)=-C_{m} M \frac{\partial}{\partial \alpha} \int\left[\frac{d V}{\left|\vec{r}_{O}-\vec{r}\right|}\right]
$$

where $\mathrm{M}$ is the magnetic dipole moment per unit volume and $\mathrm{C}_{\mathrm{m}}$ is a constant. The total magnetic induction of the object can be formulated ${ }^{[5]}$ :

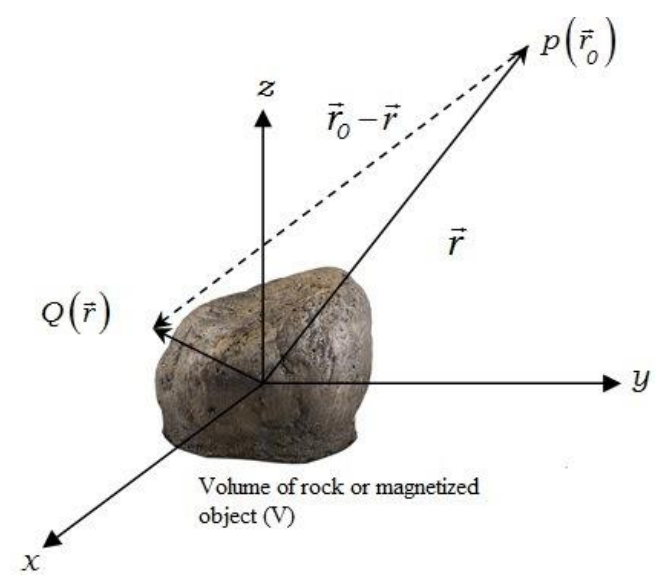

Figure 1 (Colour online). The magnetic anomaly of a magnetized subsurface object ${ }^{[5]}$.

$$
\vec{B}\left(\vec{r}_{O}\right)=C_{m} \nabla \int_{V} \vec{M}(\vec{r}) \bullet \nabla\left[\frac{1}{\left|\vec{r}_{O}-\vec{r}\right|}\right] d V
$$

The magnetic induction of equation (2) is called the magnetic anomaly, which together with the earth's main magnetic field $\left(\mathrm{B}_{0}\right)$ is measured at every point. Therefore the total magnetic field measured on the equipment is a superposition of the earth's main magnetic field and the magnetic anomaly. However in reality there is still an external magnetic field $\left(\mathrm{B}_{\mathrm{D}}\right)$ originated from the earth's atmosphere that can not be ignored (although small), so that the measured magnetic field can be expressed ${ }^{[6]}$ : 


$$
\vec{B}_{T}=\vec{B}\left(\vec{r}_{0}\right)+\vec{B}_{0}+\vec{B}_{D}
$$

\section{METHODS}

\section{Time and Location}

The research was carried out in April 2017. Data acquisition was conducted in the eastern coast area of Binangun in Cilacap Regency, particularly the coast area of Sidaurip Village and surrounding, as shown in Figure 2. The data processing, modeling, and interpretation was done in the Laboratory of Electronics, Instrumentation, and Geophysics; Faculty of Mathematics and Natural Sciences, University of Jenderal Soedirman, Purwokerto.

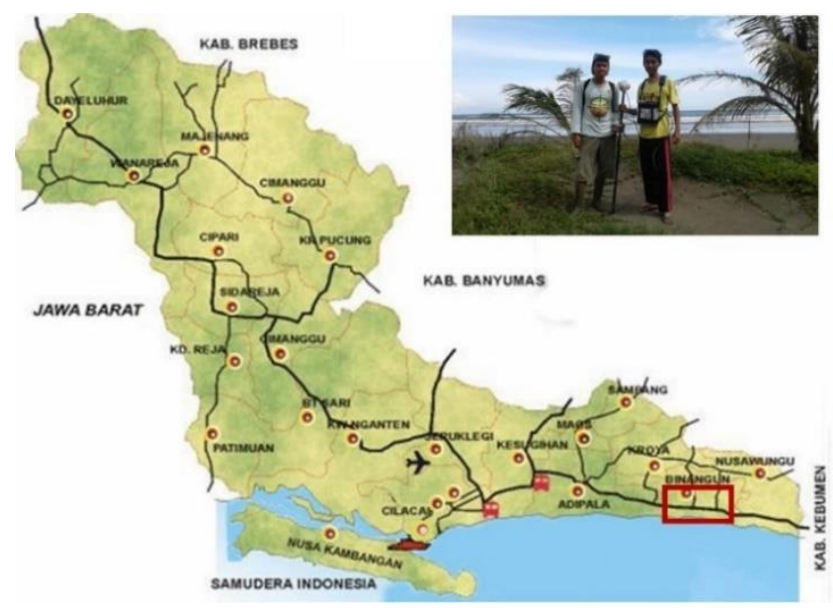

Figure 2 (Colour online). The magnetic survey location (in box) on the eastern coastal of Binangun District, Cilacap Regency

\section{Materials and Equipment}

The main equipment used in the research is Proton Precession Magnetometer GSM-19T with a measurement accuracy of 0.05nT, Global Positioning System (GPS), and compass. In addition, the supporting equipment used includes geological map of Banyumas-Cilacap, topographic map of the research area, digital camera, recording book and writing tools, laptop equipped with a printers, Microsoft Excel application, surfer 7 software, Fortran 77 program, and Mag2DC for Windows software. The listing of program for data processing of magnetic anomaly is made independently with using the Fortran 77.

\section{Research Procedure}

The research procedure used in the magnetic survey consist of data acquisition in the field, data processing, modeling and interpretation. The data obtained at each measurement point are the total magnetic intensity; the geographic position consisted of latitude, longitude, and altitude; the data acquisition time in minutes and seconds; and the environmental and surface geological conditions. To obtain the total magnetic anomaly data, the daily and the IGRF corrections are applied. The daily correction $\left(\mathrm{B}_{\mathrm{D}}\right)$ is used to remove the magnetic field deriving from the external (atmospheric), and the IGRF correction is used to remove the earth's main magnetic field value $\left(B_{0}\right)$. The total magnetic anomaly data $(\Delta B)$ is then obtained, that is following equation ${ }^{[6]}$ :

$$
\Delta B=B_{T} \pm B_{D}-B_{0}
$$


The total magnetic anomaly data obtained from equation (4) is still distributed over the topography. Mathematically this anomaly data can not be processed at a next stage if it is not distributed over a horizontal surface. Therefore, the anomaly data must be transformed into the horizontal surface. One method that can be used to transform anomalous data from uneven surface (i.e. topography) to horizontal surface is the Taylor series approximation, that is equation ${ }^{[7]}$ :

$$
\Delta B\left(\lambda, \vartheta, h_{0}\right)^{[i+1]}=\Delta B(\lambda, \vartheta, h)-\sum_{n=0}^{\infty} \frac{\left(h-h_{0}\right)^{n}}{n !} \frac{\partial^{n}}{\partial z^{n}} \Delta B\left(\lambda, \vartheta, h_{0}\right)^{[i]}
$$

Equation (5) requires an initial guests value for $\Delta \mathrm{B}\left(\lambda, \vartheta, \mathrm{h}_{0}\right)^{[\mathrm{i}]}$. In this case the initial guess is $\Delta \mathrm{B}(\lambda, \vartheta, \mathrm{h})$, which is the anomaly data distributed over the topography. Therefore, $\Delta \mathrm{B}$ $\left(\lambda, \vartheta, h_{0}\right)$ which is the anomaly data distributed over the horizontal surface is estimated by the approach. The value of $\Delta \mathrm{B}\left(\lambda, \vartheta, \mathrm{h}_{0}\right)$ obtained from the $i$-th iteration can be used to estimate the value of $\Delta \mathrm{B}\left(\lambda, \vartheta, \mathrm{h}_{0}\right)$ at the next iteration or $(i+1)$-th. This iteration should be done sufficiently, such that the obtained value of $\Delta \mathrm{B}\left(\lambda, \vartheta, \mathrm{h}_{0}\right)$ shows convergent.

Since the target in this research is iron sand, the magnetic anomaly data distributed over the horizontal surface needs to be corrected from the magnetic effects originated from deeply and widely subsurface magnetic objects, which commonly called as the regional anomaly ${ }^{[8]}$. The regional magnetic anomaly data can obtained by upward continuation process of the magnetic anomaly data to a certain height, such that the anomaly data interval shows very fine and small ${ }^{[9]}$. The upward continuation equation is derived from the Green's theorem i.e. equation ${ }^{[7]}$ :

$$
\Delta B\left(\lambda^{\prime}, \vartheta^{\prime}, h_{0}+\Delta h\right)=\frac{\Delta h}{2 \pi} \int_{-\infty}^{\infty} \int_{-\infty}^{\infty} \frac{\Delta B\left(\lambda, \vartheta, h_{0}\right)}{\sqrt{\left(\left(\lambda^{\prime}-\lambda\right)^{2}+\left(\vartheta^{\prime}-\vartheta\right)^{2}+\Delta h^{2}\right)^{3 / 2}}} d \lambda d \vartheta
$$

The regional magnetic anomaly data obtained from equation (6) is corrected for the total magnetic anomaly data in equation (5), thus be obtained the local magnetic anomaly data that expressed as equation ${ }^{[6]}$ :

$$
\Delta B_{\text {Lokal }}=\Delta B\left(\lambda, \vartheta, h_{0}\right)-\Delta B\left(\lambda^{\prime}, \vartheta^{\prime}, h_{0}+\Delta h\right)
$$

Generally, the local magnetic anomaly is targeted data in the research, which comes from mineral or rock magnetized in the earth's crust near the surface, which further used as the basis for modeling ${ }^{[10]}$.

The modeling of anomalous objects has been done using Mag2DC for Windows software by matching between the model anomaly curves obtained from the calculation againts to the observation anomaly curve obtained from the measurement. After a match is achieved, then a number of objects that assumed as subsurface rocks of the research area are obtained. The deviation of modeling results is calculated based on the equation ${ }^{[11]}$ :

$$
R=\frac{1}{n} \sqrt{\sum_{i=1}^{n}\left(\Delta B_{o b s[i]}-\Delta B_{m o[i]}\right)^{2}}
$$

where $\Delta \mathrm{B}_{\mathrm{obs}}$ is the observed anomaly data from measurement and $\Delta \mathrm{B}_{\mathrm{mo}}$ is the model anomaly data from calculation. The anomalous objects model obtained, is then interpreted to 
identify the types of rocks and its formations based on the magnetic susceptibility value of each object and supported by the geological information of the research area.

\section{RESULT AND DISCUSSION}

\section{Result of Acquisition and Processing of Magnetic Field Data}

Acquisition of magnetic data has been done at 146 points which distributed over the geographic coordinate range of $109.2699^{\circ} \mathrm{E}-109.2982^{\circ} \mathrm{E}$ and $7.6851^{\circ} \mathrm{S}-7.7019^{\circ} \mathrm{S}$. The total magnetic field intensity data at each point is 44,621.42 - 45,537.00 nT. To obtain the total magnetic anomaly data, then the daily and IGRF corrections like equation (4) were performed. Based on the results of online calculations, IGRF value of this research area is $44,999.00 \mathrm{nT}{ }^{[12]}$. After corrections, then obtained the total magnetic anomaly data values distributed over the topographic surface, that are $-374.34-552.82 \mathrm{nT}$. The contour map of the total magnetic anomaly distributed over the topographic surface is shown in Figure 3.

Furthermore, the magnetic anomaly data is transformed from the topographic surface to the horizontal surface such as following equation (5). The horizontal surface is selected on the average topographic height i.e. 23.71 meters above the reference spheroide, such that the iteration process in Taylor series rapidly achieves convergence ${ }^{[7]}$. The obtained total magnetic anomaly data has values i.e. $-274.44-396.07 \mathrm{nT}$, with the contour map shown in Figure 4. The interval between maximum and minimum anomaly values are $670.51 \mathrm{nT}$, which is relatively smaller than the anomaly value interval when it is still distributed over the topographic surface, i.e. 927.16nT. This indicates that the iteration process has reached convergence, so the anomaly data is assumed to have been distributed over the horizontal surface $^{[7]}$.

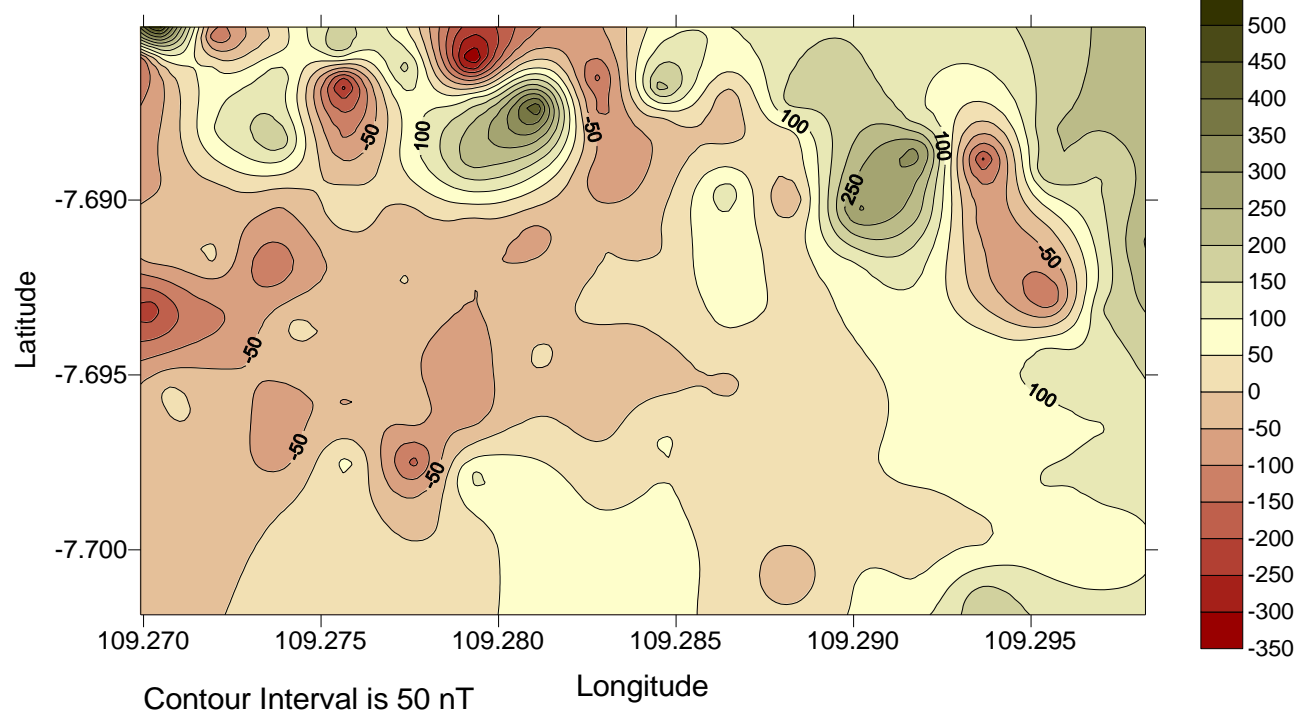

Figure 3 (Colour online). The contour map of the total magnetic anomaly distributed over the topographic surface in the research area

The research target is the local and shallow subsurface rock, i.e. iron sand. Therefore, the regional magnetic effect must be reduced according to equation (7). The regional magnetic effect is magnetic effects assumed to originate from very deep and wide objects. The value of the regional magnetic anomaly is obtained by upward continuation process of the total 
magnetic anomaly data distributed over the horizontal surface to a height of 3,250 meters. The upward continuation of anomaly data is done up to such the height because the interval of anomaly data between one location point to another location point around it shown a very small value, and the contour lines in the map pattern tends to be stable.

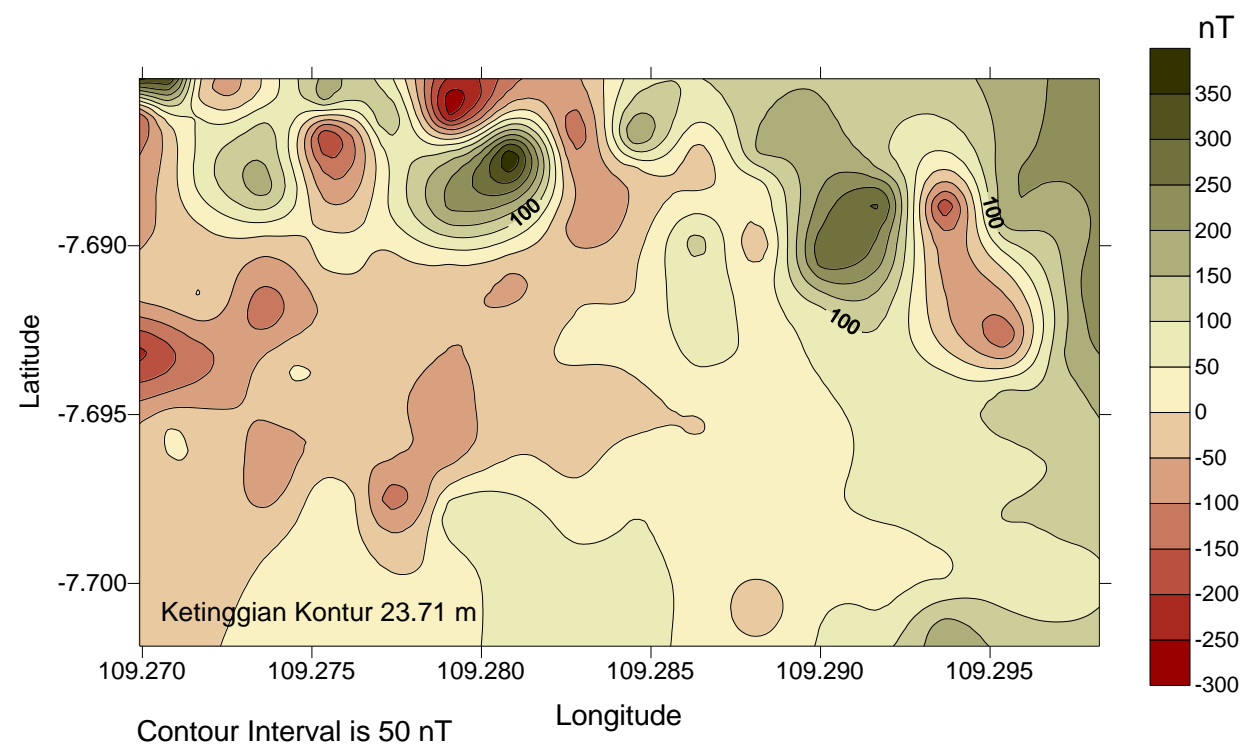

Figure 4 (Colour online). The contour map of the total magnetic anomaly distributed over the horizontal surface in the research area.

The regional magnetic anomaly data is then corrected to the total magnetic anomaly data as equation (7) to obtain the local magnetic anomaly data. The local magnetic anomaly data is at the average topographic heighs i.e. 23.71 meters. The contour map is shown in Figure 5. Based on the contour map, it is known that the centers of magnetic anomaly are much concentrated in the northern part of the research area. This indicates that according to the observation in the field, in the northern part of the research area found a lot of iron sand. The magnetic susceptibility value of iron ore is relatively so large, that it contributes greatly to the magnetic anomaly value measured on the surface ${ }^{[4]}$.

To investigate the distribution of iron sand in the research area, modeling is conducted. The modeling is done by creating a trajectory over the local anomaly contour map through some centers of magnetic anomaly that is prospectly predicted to contain iron ore. The modeling is done on the local magnetic anomaly data along the trajectory $\mathrm{AB}$, where the modeled anomaly data is extracted from the trajectory. The trajectory AB which is created above the local magnetic anomaly contour map also can be seen in Figure 5.

\section{Modeling Results and Interpretation}

In the modelling of the subsurface anomalous objects, several parameters are required as shown in Table 1 . The modeling is done on the magnetic anomaly data along the trajectory $\mathrm{AB}$, with position from point $\mathrm{A}$ at $109.2747^{\circ} \mathrm{E}$ and $7.6866^{\circ} \mathrm{S}$ to point $\mathrm{B}$ at $109.2962^{\circ} \mathrm{E}$ and $7.6891^{\circ} \mathrm{S}$. The direction of trajectory $\mathrm{AB}$ is $5.8^{\circ}$ relative from west to north, with a length of 2,408.95 meters. The modeling of the anomaly data was performed by matching the model anomaly curves resulting from the calculation against the observation anomaly curves from the measurement. The matching between two curves gives ten of anomalous objects interpreted as the subsurface rocks in research area, as shown in Figure 6. Based on equation (8), the measurements error in the modelling is $0.58 \mathrm{nT}$. 


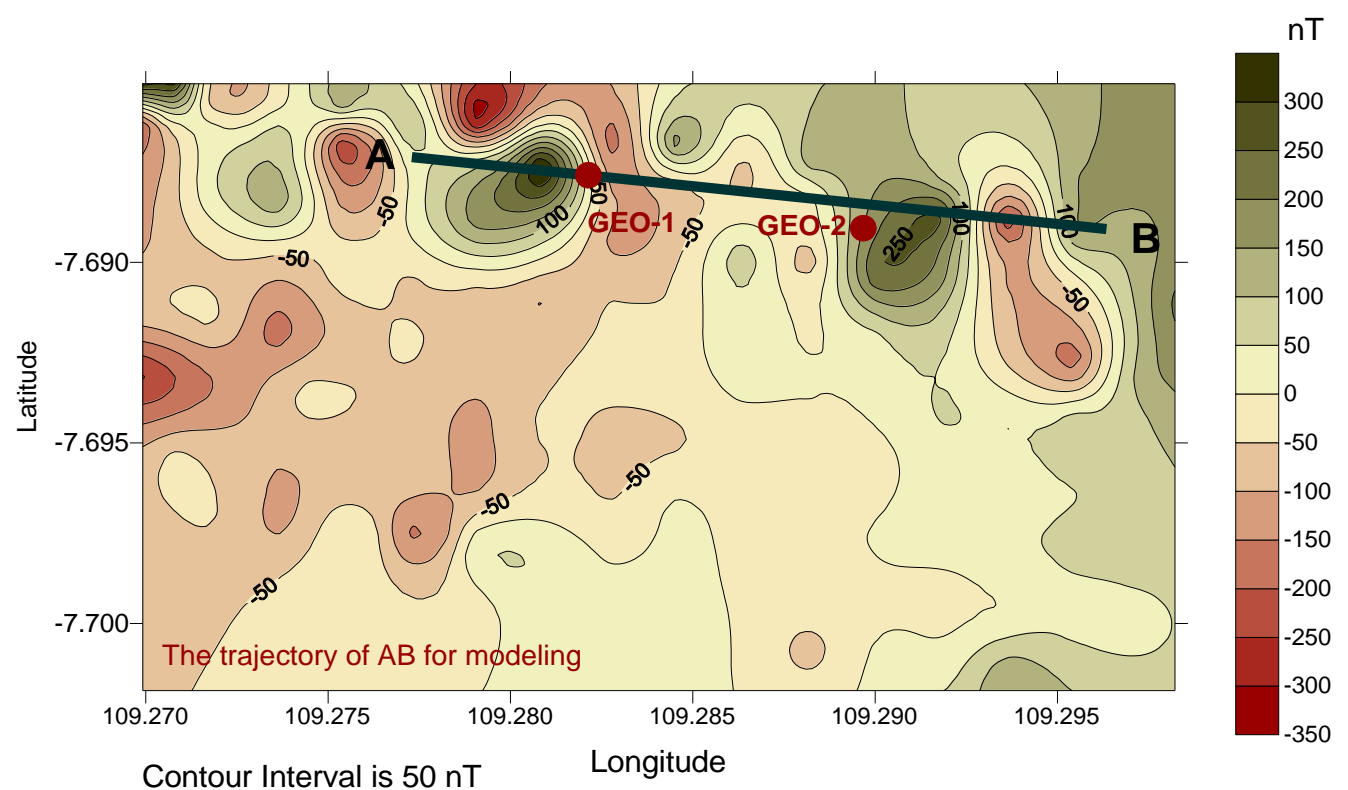

Figure 5 (Colour online). The contour map of local magnetic anomaly in the research area and the trajectory of $\mathrm{AB}$ for modeling. (Geo-1 and Geo-2 are locations of geoelectric sounding points in the research area)

Tabel 1. Several modeling parameters of magnetic anomaly in the research area

\begin{tabular}{clc}
\hline No. & \multicolumn{1}{c}{ Parameter of Model } & Value \\
\hline 1 & International Geomagnetic Reference Field & $44,999.00 \mathrm{nT}$ \\
2 & (IGRF) & $-32.4162^{\circ}$ \\
3 & Declination angle & $0.8505^{\circ}$ \\
4 & Strike lenght & 100.00 meters \\
5 & Number of anomalous objects from modeling & 10 pieces \\
6 & Interval of magnetic susceptibility contrast & $-0.0032-0.0103$ cgs unit \\
7 & Interval of anomalous objects depth & $1,709-204,274$ meters \\
\hline
\end{tabular}

According to the geological information, the rocks containing iron ore are from the coastal alluvium ${ }^{[13]}$. This geological information is corresponding to the local magnetic anomaly contours map, since the entire research area is located in the coastal area of Cilacap, which covered by alluvium formation, including the coastal alluvium. The presence of iron ore is estimated to be distributed over the high anomalous zone, i.e. around the trajectory of $A B$, as shown in Figure 5. Based on the geological map, the average rock in the research area is interpreted as silt, clay, sand, and gravel containing iron ore granules from the alluvium formation; and alternate mixture of sandstones, claystone, napal, and tuff that inserted with breccias from the Halang formation ${ }^{[13,14]}$. 


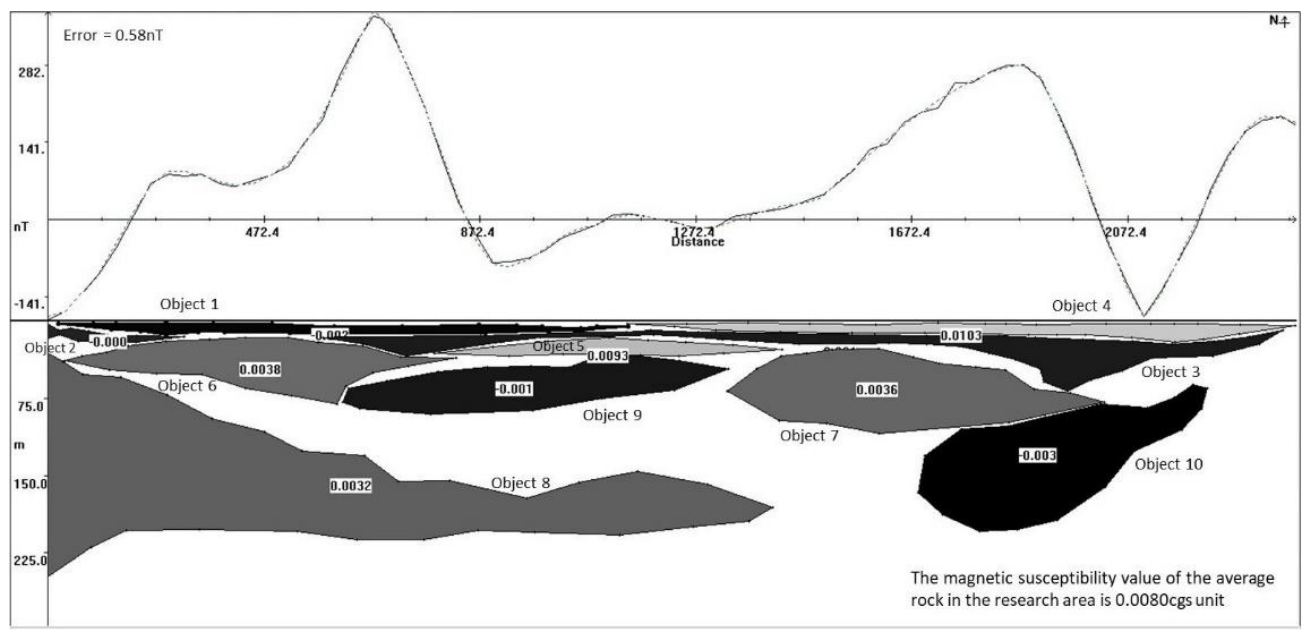

Figure 6. The modeling result using Mag2DC for Windows software on the magnetic anomaly data along the trajectory of $\mathrm{AB}$ and its interpretation (equipped the magnetic susceptibility contrast value of each model object).

Interpretation of the rocks types and its formations was done to the subsurface anomalous objects obtained from the modeling. Furthermore, the estimation of magnetic susceptibility value of the average rock in the research area has to be set. Based on the previous research results at the western coastal of Binangun, the magnetic susceptibility value of the average rock in the research area is estimated to be $0.0080 \mathrm{cgs}$ unit ${ }^{[14]}$. Geologically, the eastern coastal of Binangun are not different from the western coastal, and hence the magnetic susceptibility value of average rock is also assumed to be same. Then the magnetic susceptibility value of each anomaly object $(\chi)$ can be obtained by the sum of the magnetic susceptibility value of the average rock in the research area and the magnetic susceptibility contrast value of each object $(\Delta \chi)$, as shown in Table 2 .

Table 2. Result of interpretation of rocks types and its formation along the trajectory of $A B$

\begin{tabular}{|c|c|c|c|c|c|}
\hline No. & $\begin{array}{l}\text { Anomaly } \\
\text { Object }\end{array}$ & $\begin{array}{l}\text { Depth } \\
\text { (meter) }\end{array}$ & $\begin{array}{c}\Delta \chi \\
(\mathbf{c g s} \\
\text { units })\end{array}$ & $\begin{array}{l}\text { Estimasi } \\
\chi \text { (cgs } \\
\text { units) } \\
\end{array}$ & $\begin{array}{l}\text { Interpretation of Rocks Types and } \\
\text { its Formations }\end{array}$ \\
\hline 1 & Object 1 & $2.137-13.105$ & -0.0020 & 0.0060 & \multirow{3}{*}{$\begin{array}{l}\text { Silt, clay, sand, and gravel that con- } \\
\text { taining iron ore from the alluvium } \\
\text { formation }\end{array}$} \\
\hline 2 & Object 2 & $2.849-20.513$ & -0.0008 & 0.0072 & \\
\hline 3 & Object 3 & $8.547-67.806$ & -0.0013 & 0.0067 & \\
\hline 4 & Object 4 & $1.709-20.513$ & 0.0103 & 0.0183 & \multirow{2}{*}{$\begin{array}{l}\text { Iron sand that coexists with silt, and } \\
\text { clay from the alluvium formation }\end{array}$} \\
\hline 5 & Object 5 & $16.524-34.188$ & 0.0094 & 0.0174 & \\
\hline 6 & Object 6 & $15.954-80.342$ & 0.0039 & 0.0119 & \multirow{3}{*}{$\begin{array}{l}\text { Breccia of andesite, basaltic rocks, } \\
\text { and limestone insert with sandstone } \\
\text { and basaltic lava from the Halang } \\
\text { formation }\end{array}$} \\
\hline 7 & Object 7 & 26.781 & 0.0036 & 0.0116 & \\
\hline 8 & Object 8 & $31.624-247.863$ & 0.0032 & 0.0112 & \\
\hline 9 & Object 9 & $33.618-90.028$ & -0.0016 & 0.0064 & \multirow{2}{*}{$\begin{array}{l}\text { Limestone insert with sandstones } \\
\text { from the Halang formation }\end{array}$} \\
\hline 10 & Object 10 & 61.538-204.274 & -0.0032 & 0.0048 & \\
\hline
\end{tabular}


The results of modeling and interpretation on the local magnetic anomaly data shows two objects under the trajectory of $\mathrm{AB}$ which that interpreted as iron sand inserted alternately by silt and clay from the alluvium formation. The first has a length of 1238.204 meters, a depth of $1.709-20.513$ meters and a magnetic susceptibility value of $0.0183 \mathrm{cgs}$ unit. The second has a length of 643,055 meters, a depth of 16.524 - 34.188 meters, and a magnetic susceptibility value of $0.0174 \mathrm{cgs}$ unit. Furthermore, the obtained subsurface iron sand are estimated very prospective to be exploited for its iron ore content.

Based on the interpretation results, the iron ore is also found in other subsurface rock from the alluvium formation, though not dominant. These rocks are interpreted composed of silt, clay, sand, and gravel containing iron ore. This interpretation is based on the magnetic susceptibility values of rocks that rather large i.e. $0.0060 ; 0.0067$; and 0.0072 cgs unit. Other than the direct observation in the field also supports the interpretation. This rocks extend along the trajectory of $\mathrm{AB}$ with length of 2288.466 meters and depth of $2.137-67.806$ meters. According to research conducted by Hikmatyar (2016), the average content of iron (Fe) from the iron sand samples taken in this research area is $11.027 \%{ }^{[15]}$.

Based on the results of geoelectric survey conducted together with the magnetic survey at Geo-1 point with the position of $109.2825^{\circ} \mathrm{E}$ and $7.6873{ }^{\circ} \mathrm{S}$ and at Geo-2 point with the position of $109.2903^{\circ} \mathrm{E}$ and $7.6899^{\circ} \mathrm{S}$ as shown in Figure 5, then obtained the rocks which interpreted as iron sand mixed alternately with silt and clay from the alluvium formation. For Geo-1 point, the iron sand is interpreted to be located in third layer at a depth of $9.42-$ 19.48 meters with resistivity value of $52.99 \Omega \mathrm{m}$; and then for Geo-2 point, the iron sand is interpreted to be located in third layer at a depth of $10.56-22.20$ meters with resistivity value of $49.03 \Omega \mathrm{m}$. In addition, the iron ore granules are also found in the second layer interpreted to be composed of silt, sand, clay, and gravel that coexist with iron ore; and the first layer is the surface rock ${ }^{[13,14]}$. In general, the results of the resistivity data modeling at Geo-1 and Geo-2 points can be seen in Figure 7.
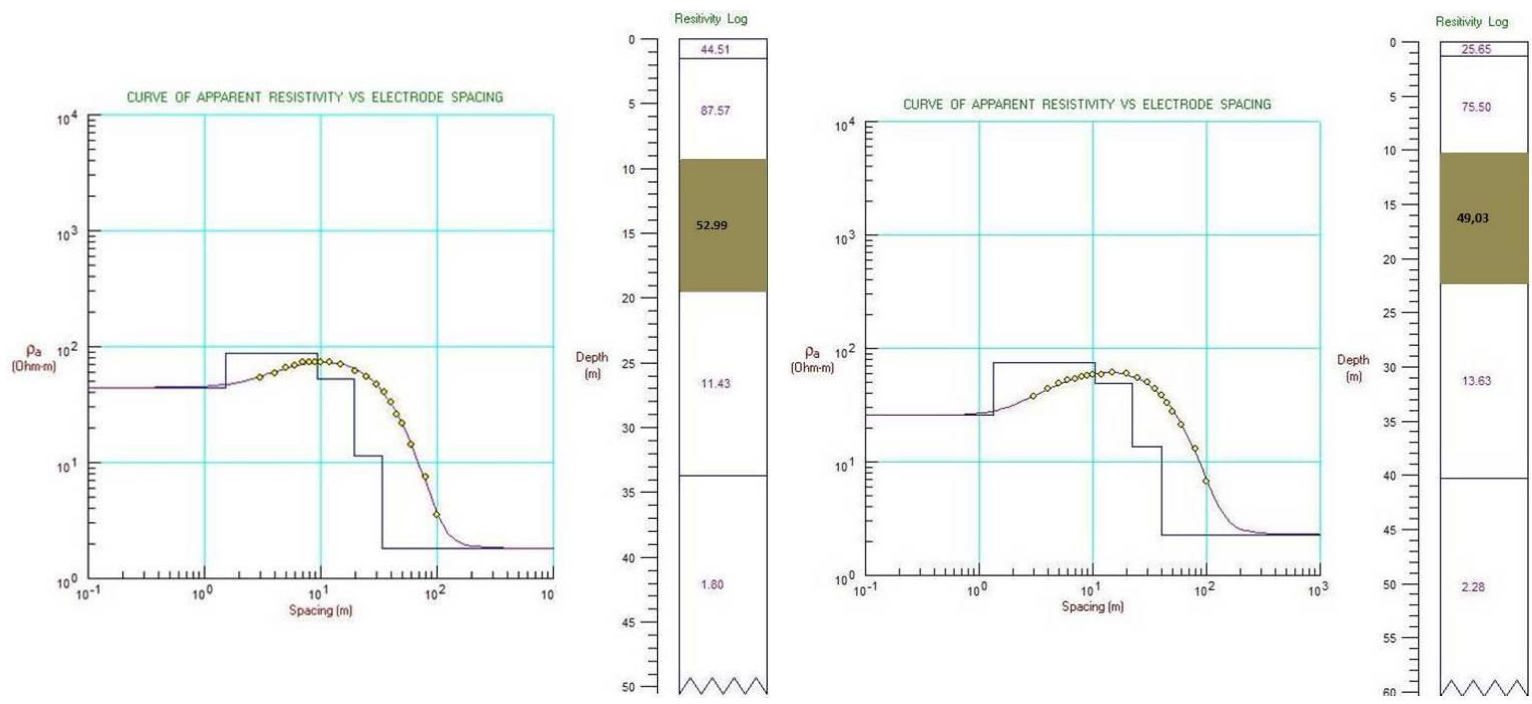

Figure 7 (Colour online). The modeling and interpretation output of the subsurface rock resistivity data of the geoelectric survey results in the research area. At the first point, the iron sand is estimated to have a resistivity value of $52.99 \Omega \mathrm{m}$; at the second point, the iron sand is estimated to have a resistivity value of $49.03 \Omega \mathrm{m}$.

Based on this research results, the economic potential of iron sand in the research area is very prospective to supply the needs of local industries. However, the alluvium formation rocks in the Binangun coastal are also playing a role to inhibit coastal abrasion rate and sea 
water intrusion into the shallow groundwater aquifer in the coastal and surrounding [16]. Therefore, the alluvium formation rocks must be conserved and should not be destroyed by the exploitation of iron sand.

\section{CONCLUSION}

Exploration of the iron sand distribution at the eastern coastal area of Binangun in Cilacap Regency has been done based on the magnetic survey. Some corrections and reductions are applied on the obtained total magnetic field data so that the local magnetic anomaly data is yielded. The modeling of the local magnetic anomaly data has been done along the trajectory of $\mathrm{AB}$ extending from the position of $109.2747^{\circ} \mathrm{E}$ and $7.6866^{\circ} \mathrm{S}$ to $109.2962^{\circ} \mathrm{E}$ and $7.6891^{\circ} \mathrm{S}$, so it can be obtained ten of the subsurface anomalous objects.

Based on the interpretation results, then be obtained two objects under the trajectory of $\mathrm{AB}$ that interpreted as iron sand that inserted alternately by silt and clay from the alluvium formation. The first has a length of 1238.204 meters, a depth of $1.709-20.513$ meters, and the magnetic susceptibility value of $0.0183 \mathrm{cgs}$ unit. While the second has a length of 643.055 meters, a depth of $16.524-34.188$ meters, and the magnetic susceptibility value of 0.0174 cgs unit. The results of research also is supported by the results of geoelectric survey analysis. The iron ore in the research area is estimated very prospective.

\section{ACNOWLEDGEMENT}

Our thanks to the General Director of Higher Education of the Ministry of Research, Technology, and Higher Education of the Republic of Indonesia; Rector of the University of Jenderal Soedirman, and Chairman of Institute for Research and Community Service (LPPM) University of Jenderal Soedirman for the acceptance of this research project and the budget provided. Thanks also to Head of Electronics, Instrumentation, and Geophysics Laboratory of the Faculty of Mathematic and Natural Science University of Jenderal Soedirman for the equipment provided. In addition our thanks also to the all research team consisting of lecturers and students who have worked hard during the magnetic field data acquisition in the field.

\section{REFERENCES}

1 Kadin Bussines Center Cilacap (KBCC). 2015. Potensi Energi dan Sumberdaya Mineral, Kamar Dagang dan Industri (KADIN) Kabupaten Cilacap. Sumber Website http://kadincilacap.or.id/tentang-cilacap/potensi/energi-sdm.html. Diakses tanggal 09 November 2016.

2 Ansori, C., Sudarsono, \& Saefudin. 2011. Distribusi Mineralogi Pasir Besi pada Jalur Pantai Selatan Kebumen - Kutoarjo. Buletin Sumberdaya Geologi, 6 (2), 81 - 96.

3 Mariita, N.O. 2007. The Magnetic Method. Short Course II on Surface Exploration for Geothermal Resources. UNU-GTP and KenGen, Lake Naivasha, Kenya. 2 - 17 November 2007.

4 Bilalodin. 2010. Kajian Sifat Magnetik dari Pasir Besi Pantai Logending Kabupaten Kebumen. Jurnal Molekul, 5 (2), 105 - 108.

5 Telford, W.M., Geldart, L.P., Sheriff, R.E. \& Keys, D.A. 1990. Applied Geophysics. Cambridge University Press. New York.

6 Sehah. 2002. Pendugaan Model Struktur Bawah Permukaan Daerah Gunungapi Batur Berdasarkan Data Anomali Magnetik. Tesis. Universitas Gadjah Mada Yogyakarta. 
7 Blakely, R.J. 1995. Potential Theory in Gravity and Magnetic Applications. Cambridge University Press. New York.

8 Ghidella, M.E., Forsberg, R., Greenbaum, J.S., Olesen, A.V., Zakrajsek, A.F., \& Blankenship, D.D. 2011. Magnetic Anomaly Data from A Regional Survey: From Tierra Del Fuego To Northern Palmer Land, Antarctic Peninsula. Latinmag Letters, 1 (Special Issue), A19, $1-7$.

9 Ganiyu, S. A., Badmus, B. S., Awoyemi, M. O., Akinyemi, O. D. \& Olurin, O. T. 2013. Upward Continuation and Reduction to Pole Process on Aeromagnetic Data of Ibadan Area, South-Western Nigeria. Earth Science Research, 2 (1), 66 - 73.

10 Marcelin B. B., Mbarga, T. N. \& Tabod, T. C. 2014. Quantitative Interpretation of Magnetic Anomalies in Ebolowa-Djoumarea (Southern Cameroon). Geophysica, 50 (1), $11-25$.

11 Suprianto. 2007. Analisis Data Geofisika: Memahami Teori Inversi. Departemen Fisika Fakultas MIPA Universitas Indonesia. Jakarta.

12 National Geophysical Data Center. 1999. Magnetic Field Calculators; Estimated Value Magnetic Field. Sumber Website: http://www.w3.org. Diakses pada tanggal 02 Mei 2017.

13 Herman, D.Z. 2005. Kegiatan Pemantauan dan Evaluasi Konservasi Sumberdaya Mineral Daerah Kabupaten Cilacap Propinsi Jawa Tengah. Kolokium Hasil Lapangan. Pusat Sumberdaya Geologi. Kementerian Energi dan Sumberdaya Mineral. Bandung.

14 Asikin, Handoyo \& Prastistho. 1992. Peta Geologi Lembar Banyumas Jawa. Pusat Penelitian dan Pengembangan Geologi. Bandung.

15 Hikmatyar, M.S. 2016. Geologi dan Karakteristik Pantai serta Kaitannya dengan Keterdapatan Pasir Besi di Pantai Selatan Cilacap, Jawa Tengah. Skripsi. Jurusan Geologi, Fakultas Teknik, Universitas Jenderal Soedirman Purwokerto.

16 Sehah, Raharjo, S. A. \& Kurniawan, M. A. 2016. Distribution of Iron Sand in the Widarapayung Coast Area at Regency of Cilacap Based on Magnetic Anomaly Data. Indonesian Journal of Applied Physics, 6 (2), 97 - 106. 